\title{
A universal carbonate ion effect on stable oxygen isotope ratios in unicellular planktonic calcifying organisms
}

\author{
P. Ziveri ${ }^{1,2}$, S. Thoms ${ }^{3}$, I. Probert ${ }^{4}$, M. Geisen ${ }^{3}$, and G. Langer ${ }^{1,3, *}$ \\ ${ }^{1}$ Institute of Environmental Science and Technology (ICTA), Universitat Autònoma de Barcelona (UAB), \\ Bellaterra, 08193, Spain \\ ${ }^{2}$ Cluster Earth \& Climate, Department of Earth Sciences, FALW, VU Universiteit Amsterdam, de Boelelaan 1085 1081HV \\ Amsterdam, The Netherlands \\ ${ }^{3}$ Alfred Wegener Institute for Polar and Marine Research, Bremerhaven, Germany \\ ${ }^{4}$ FR2424, CNRS/UPMC, Station Biologique de Roscoff, 29682 Roscoff, France \\ * present address: Department of Earth Sciences, Cambridge University Downing St., Cambridge CB2 3EQ, UK
}

Correspondence to: P. Ziveri (patrizia.ziveri@uab.es)

Received: 23 May 2011 - Published in Biogeosciences Discuss.: 1 August 2011

Revised: 16 February 2012 - Accepted: 16 February 2012 - Published: 15 March 2012

\begin{abstract}
The oxygen isotopic composition $\left(\delta^{18} \mathrm{O}\right)$ of calcium carbonate of planktonic calcifying organisms is a key tool for reconstructing both past seawater temperature and salinity. The calibration of paloeceanographic proxies relies in general on empirical relationships derived from field experiments on extant species. Laboratory experiments have more often than not revealed that variables other than the target parameter influence the proxy signal, which makes proxy calibration a challenging task. Understanding these secondary or "vital" effects is crucial for increasing proxy accuracy. We present data from laboratory experiments showing that oxygen isotope fractionation during calcification in the coccolithophore Calcidiscus leptoporus and the calcareous dinoflagellate Thoracosphaera heimii is dependent on carbonate chemistry of seawater in addition to its dependence on temperature. A similar result has previously been reported for planktonic foraminifera, supporting the idea that the $\left[\mathrm{CO}_{3}^{2-}\right]$ effect on $\delta^{18} \mathrm{O}$ is universal for unicellular calcifying planktonic organisms. The slopes of the $\delta^{18} \mathrm{O} /\left[\mathrm{CO}_{3}^{2-}\right]$ relationships range between $-0.0243 \% \circ\left(\mu \mathrm{mol} \mathrm{kg}^{-1}\right)^{-1}$ (calcareous dinoflagellate $T$. heimii) and the previously published $-0.0022 \%$ o $\left(\mu \mathrm{mol} \mathrm{kg}{ }^{-1}\right)^{-1}$ (non-symbiotic planktonic foramifera Orbulina universa), while C. leptoporus has a slope of $-0.0048 \%$ o $\left(\mu \mathrm{mol} \mathrm{kg}{ }^{-1}\right)^{-1}$. We present a simple conceptual model, based on the contribution of $\delta^{18} \mathrm{O}$-enriched $\mathrm{HCO}_{3}^{-}$ to the $\mathrm{CO}_{3}^{2-}$ pool in the calcifying vesicle, which can explain the $\left[\mathrm{CO}_{3}^{2-}\right]$ effect on $\delta^{18} \mathrm{O}$ for the different unicellular calcifiers. This approach provides a new insight into
\end{abstract}

biological fractionation in calcifying organisms. The large range in $\delta^{18} \mathrm{O} /\left[\mathrm{CO}_{3}^{2-}\right]$ slopes should possibly be explored as a means for paleoreconstruction of surface $\left[\mathrm{CO}_{3}^{2-}\right]$, particularly through comparison of the response in ecologically similar planktonic organisms.

\section{Introduction}

Calcification by marine organisms is a key component of the global carbon cycle. Planktonic calcifying organisms are particularly significant since they are responsible for more than $80 \%$ of global $\mathrm{CaCO}_{3}$ production and a high proportion of their shells is exported to the seafloor to form carbonate sediments (Milliman, 1993).

The unicellular coccolithophore algae, members of the division Haptophyta, are among the major primary producers and calcifiers worldwide. Coccolithophores are present in virtually all photic zone marine environments (Baumann et al., 2005; Thierstein and Young, 2004) and together with planktic foraminifera they dominate carbonate production in the open ocean (Ziveri et al., 2007; Broecker and Clark, 2008). Another group of planktonic calcifying organisms is a monophyletic lineage of peridiniphycidean dinoflagellates that live in the upper water column where light is available for photosynthesis and during their life cycle produce cysts that are characterized by the incorporation of calcite in at least one layer of the cyst wall. 
The chemical composition of the calcite produced by these organisms (i.e., foraminiferal tests, the coccoliths of coccolithophores and the cysts of calcareous dinoflagellates) provides a unique source of information with regard to paleoclimatological studies (e.g., Erez and Luz, 1983; Stoll and Ziveri, 2004; Katz et al., 2010)

The oxygen isotope composition of carbonate fossils has been used to reconstruct the most sought-after target in paleoceanography, the sea surface temperature (SST). The $\delta^{18} \mathrm{O}$ temperature relationship is well characterized in foraminifera (Bemis et al., 1998) and has also been studied in coccolithophores (Ziveri et al., 2003 and references therein) and calcareous dinoflagellate cysts (Zonneveld et al., 2007). In addition to the temperature effect, a dependence of oxygen isotope fractionation on the carbonate chemistry of seawater was demonstrated in four planktic foraminiferal species (Spero et al., 1997; Bijma et al., 1999). A decrease in fractionation with increasing carbonate ion concentration was recorded in tests of these species, but the slopes for this relationship differed by a factor of up to two. The more gentle of the slopes was explained in terms of the isotopic composition of the sum of the carbon species in seawater (Zeebe, 1999), but the steeper slope has remained unexplained to date.

The influence of carbonate chemistry on the oxygen isotope fractionation of coccolithophores and calcareous cyst producing dinoflagellates has never been studied. We therefore conducted controlled laboratory experiments using one of the most important calcite producers among the coccolithophores, Calcidiscus leptoporus (Ziveri et al., 2007), as well as the most abundant living calcareous dinoflagellate, Thoracosphaera heimii. The carbonate chemistry of seawater was altered to determine its impact on oxygen isotope fractionation during calcification. Based on our experimental data, we propose a simple conceptual model that can explain the different $\delta^{18} \mathrm{O}$ slopes in terms of a different contribution of $\mathrm{HCO}_{3}^{-}$conversion to $\mathrm{CO}_{3}^{2-}$ to the establishment of supersaturation with respect to calcite in the calcification vesicle. This model is subsequently applied to explain the data previously obtained from studies on planktic foraminifera (Spero et al., 1997; Bijma et al., 1999).

\section{Culture experiments}

\subsection{Experimental design and sampling}

Clonal cultures of Calcidiscus leptoporus (strains RCC1154, formerly known as AC360 and AS31 from the Alboran Sea off Spain, and RCC1135 formerly known as AC365 and NS6-1 from the South Atlantic off South Africa) and of T. heimii (strain RCC1511 formerly known as JF1 from the Pacific Ocean) from the Roscoff Culture Collection, (http: //www.sb-roscoff.fr/Phyto/RCC/) were grown in sterile filtered $(0.2 \mu \mathrm{m})$ seawater enriched with $100 \mu \mathrm{M}$ nitrate and $6.25 \mu \mathrm{M}$ phosphate and with trace metal and vitamin sup- plements according to f/2(-Si) (Guillard and Ryther, 1962). The incident photon flux density was $350 \mu \mathrm{mol} \mathrm{m}^{-2} \mathrm{~s}^{-1}$ and a 16/8 h light/dark cycle was applied. Experiments were carried out at $20^{\circ} \mathrm{C}$ for C. leptoporus and $17^{\circ} \mathrm{C}$ for T. heimii. Cells were acclimated to experimental conditions for approximately 10 generations and grown in dilute batch cultures in triplicate (Langer et al., 2006). Low cell density at harvest (in general less than 6000 cells per $\mathrm{ml}$ ) resulted in less than $8 \%$ DIC (dissolved inorganic carbon) consumption (i.e., DIC consumed by the cells at the end of experiment) and a shift in $\mathrm{pH}$ of no more than 0.06 units.

The carbonate system of seawater can be manipulated in various ways. Changes in atmospheric $p \mathrm{CO}_{2}$ can be used to alter $\left[\mathrm{CO}_{2}\right], \mathrm{pH}$ and DIC, with TA (total alkalinity) remaining constant. Manipulating $p \mathrm{CO}_{2}$ requires bubbling with $\mathrm{CO}_{2}$ gas (constantly throughout the experiment if an open system is employed). Alternatively, the addition of the acid $\mathrm{HCl}$ or the base $\mathrm{NaOH}$ can be used to adjust $\left[\mathrm{CO}_{2}\right], \mathrm{pH}$, and $\mathrm{TA}$, with DIC remaining constant. Both methods, TA manipulation (C. leptoporus) and DIC manipulation (T. heimii), were employed in this study, in both cases in closed systems (see below). It should be noted that chemical changes imposed by the two methods are of similar magnitude. The $p \mathrm{CO}_{2}$ range typically used in experiments is $\sim 180$ to $\sim 1000 \mu$ atm. This range can be covered by either increasing DIC by approximately $15 \%$ or decreasing TA by approximately $15 \%$ (to increase $\left[\mathrm{CO}_{2}\right]$ ). The change in either DIC or TA is small compared to the changes in $\mathrm{CO}_{2}$ concentration at the upper limit (increase by a factor of $\sim 6$ ), $\mathrm{CO}_{3}^{2-}$ concentration (decrease by a factor of $\sim 4$ ), and $\mathrm{H}^{+}$concentration (increase by a factor of $\sim 5$, i.e., a $\mathrm{pH}$ drop of $\sim 0.7$ units) (for details on the carbonate system refer to Zeebe and Wolf-Gladrow, 2001). Experiments in which DIC is altered should thus be comparable to experiments in which TA is altered (Schulz et al., 2009; Hoppe et al., 2011).

In order to prevent gas exchange with the atmosphere in our experiments, $2.4 \mathrm{~L}$ flasks were filled without headspace and closed with Teflon-lined screw caps. Determination of cell density, however, required regular sampling for cell counts, thereby creating a maximum headspace of $6 \mathrm{ml}$, and resulting in a negligible shift $(3 \%)$ in $\mathrm{CO}_{2}(\mathrm{aq})$ concentration. Samples for alkalinity measurements were filtered $\left(0.6 \mu \mathrm{m}\right.$ pore size), poisoned with $1 \mathrm{~mL}$ of a $\mathrm{HgCl}_{2}$ solution $\left(35 \mathrm{gl}^{-1}\right)$ and stored in $300 \mathrm{~mL}$ borosilicate flasks at $0{ }^{\circ} \mathrm{C}$. DIC samples were sterile filtered using a syringe filter $(0.2 \mu \mathrm{m})$ and stored in $13 \mathrm{~mL}$ borosilicate flasks free of air bubbles at $0{ }^{\circ} \mathrm{C}$. Total alkalinity was calculated from linear Gran plots (Gran, 1952) after duplicate potentiometric titration (Bradshaw et al., 1981; Brewer et al., 1986) and DIC was measured photometrically (Stoll et al., 2001) in triplicate. Precision of the total alkalinity measurements was $\sim 3 \mu \mathrm{mol} \mathrm{L}-1$ and accuracy $\sim 4 \mu \mathrm{mol} \mathrm{L}^{-1}$. For DIC, precision was $\sim 4 \mu \mathrm{mol} \mathrm{L}^{-1}$ and accuracy $\sim 5 \mu \mathrm{mol} \mathrm{L}-1$. The carbonate system was calculated from temperature, salinity, and the concentrations of DIC, total alkalinity and phosphate, using 
the $\mathrm{CO}_{2} \mathrm{SYS}$ software (Lewis and Wallace, 1998). Equilibrium constants of Mehrbach et al. (1973) refitted by Dickson and Millero (1987) were chosen.

Cell samples for oxygen and carbon isotope analysis were centrifuged in $50 \mathrm{~mL}$ Falcon tubes, centrifuged again in $1 \mathrm{~mL}$ tubes in order to remove seawater, dried at $60^{\circ} \mathrm{C}$ for $48 \mathrm{~h}$, and stored at room temperature. After the last centrifugation step, care was taken to remove as much of the seawater medium as possible in order to minimize contamination due to residual salts. Seawater samples for isotope analysis were sterile filtered $(0.2 \mu \mathrm{m})$, poisoned with $\mathrm{HgCl}$, and stored in gas tight bottles at room temperature prior to analysis. For determination of cell density, samples were taken daily or every other day, stored at $0^{\circ} \mathrm{C}$ and counted within $3 \mathrm{~h}$ of sampling using a Sedgwick Rafter counting cell.

\subsection{Sample preparation and measurement of isotope ratios}

The $\delta^{18} \mathrm{O}$ of water samples from the C. leptoporus experiments was measured at the Leibniz Laboratory, Kiel University, on a Finnigan Delta E connected with an equilibration bath (Equi). An aliquot of the sample water was isotopically equilibrated with an external $\mathrm{CO}_{2}$, this $\mathrm{CO}_{2}$ was extracted, analyzed by mass spectrometer, and $\delta^{18} \mathrm{O}$ calculated from the isotope composition. $\delta^{18} \mathrm{O}$ calibration of the working reference gas was based on VSMOW, with a fine correction derived from analysis of VSMOW, GISP, and SLAP. This calibration was performed once or twice a year. The stability control in routine operation used internal water standards of different isotopic composition. As with the DIC sample series, a second gas standard was measured at the end of each sample batch. The $1 \sigma$ standard deviation of water samples was \pm 0.05 for $\delta^{18} \mathrm{O}$. The poisoned filtered medium samples from the T. heimii culture experiments were measured at the Vrije Universiteit (Amsterdam) using an on-line gas preparation (Finnigan GasBench II). The $1 \sigma$ standard deviation of water samples for $\delta^{18} \mathrm{O}$ was \pm 0.05 . Reproducibility tests were based on a routinely run laboratory water standard (Vienna-Standard Mean Ocean Water (V-SMOW)). $\delta^{18} \mathrm{O}$ values ranged from -0.33 to $0.09 \%$ (SMOW).

The stable isotopes of coccolith and calcareous dinoflagellate samples were measured at the Vrije Universiteit (Amsterdam) using a CARBO-KIEL automated carbonate preparation device linked on-line to a Finnigan MAT252 mass spectrometer (Kiel device). The reproducibility of a routinely analyzed carbonate standard (GICS) was better than $0.15 \%$ for $\delta^{18} \mathrm{O}$ for the MAT252. Based on replicate analyses of splits of culture samples, the mean reproducibility of the $\delta^{18} \mathrm{O}$ measurements was better than $\pm 0.2 \%$ 。

\section{Experimental results and discussion}

Carbonate ion concentration in the seawater medium in which the cells were grown, calculated using $\mathrm{CO}_{2}$ SYS (Lewis and Wallace, 1998), ranged from 78 to $530 \mu \mathrm{mol} \mathrm{kg}^{-1}$ for C. leptoporus experiments and from 117 to $239 \mu \mathrm{mol} \mathrm{kg}{ }^{-1}$ for $T$. heimii experiments. The $\delta^{18} \mathrm{O}$ in coccoliths of $C$. leptoporus was inversely correlated with the computed $\left[\mathrm{CO}_{3}^{2-}\right]$ with a regression slope of -0.0048 $\left(\% \circ\left(\mu \mathrm{mol} \mathrm{kg}{ }^{-1}\right)\right)\left(r^{2}=0.89\right)$, (Fig. 1). The $\delta^{18} \mathrm{O}$ in T. heimii calcite exhibited the same type of inverse relationship with $\left[\mathrm{CO}_{3}^{2-}\right]$, but with a regression slope of $-0.0243(\%$ o $(\mu \mathrm{mol} \mathrm{kg}-1))\left(r^{2}=0.95\right)$. The $1 \sigma$ confidence bounds are shown in Fig. 1. Oxygen isotope fractionation in these two phylogenetically distant unicellular planktonic calcifying taxa, as well as in two planktonic Foraminifera (Spero et al., 1997; Bijma et al., 1999), thus consistently decreases with increasing $\left[\mathrm{CO}_{3}^{2-}\right]$ of seawater. This relationship suggests a common oxygen isotope fractionation mechanism. We propose below a conceptual model that can explain the different slopes identified in this and previous studies based on the contribution of $\mathrm{HCO}_{3}^{-}$to the $\mathrm{CO}_{3}^{2-}$ pool in the calcifying vesicle.

The slopes of the $\delta^{18} \mathrm{O} /\left[\mathrm{CO}_{3}^{2-}\right]$ relationships for tested planktonic calcifiers range from $-0.0022 \% o\left(\mu \mathrm{mol} \mathrm{kg}{ }^{-1}\right)^{-1}$ for the foraminifer Orbulina universa to $-0.0243 \%$ o $\left(\mu \mathrm{mol} \mathrm{kg}{ }^{-1}\right)^{-1}$ for the calcareous dinoflagellate T. heimii (Fig. 1). T. heimii has a steep slope which suggests strong biological control on oxygen isotope fractionation. Of the species analyzed to date, T. heimii shows the largest dissimilarity in $\delta^{18} \mathrm{O} /\left[\mathrm{CO}_{3}^{2-}\right]$ slope between biological and inorganic precipitates (Spero et al., 1997; Zeebe, 1999). The heavily calcified coccolithophore $C$. leptoporus has a $\delta^{18} \mathrm{O} /\left[\mathrm{CO}_{3}^{2-}\right]$ slope of $-0.0048 \%$ o $\left.(\mu \mathrm{mol} \mathrm{kg})^{-1}\right)^{-1}$, similar to that for inorganic precipitates and for the planktonic foraminifer G. bulloides, but steeper than the slope reported for $O$. universa (Spero et al., 1997).

In coccolithophores, precipitation of calcite takes place intracellularly within a calcifying vesicle, a membranedelimited space that is completely isolated from the cytoplasm (e.g., Young et al., 1999). While the $\mathrm{pH}$ in the external medium can change under different environmental conditions, cellular $\mathrm{pH}$-homeostasis should keep the $\mathrm{pH}$ inside the vesicle constant at an alkaline value favorable for calcite precipitation.

Interestingly, a similar vesicle-based calcification mechanism has been proposed for the common calcareous dinoflagellate T. heimii (Inouye and Pienaar, 1983). Although planktic foraminifera are thought to calcify in an extracellular space (Spero, 1988), the role of seawater endocytosis in the biomineralization process in calcareous foraminifera (Bentov et al., 2009) is indeed remarkably similar to the one of coccolithophores and T. heimii. This is supported by $\mathrm{Mg} / \mathrm{Ca}$ 


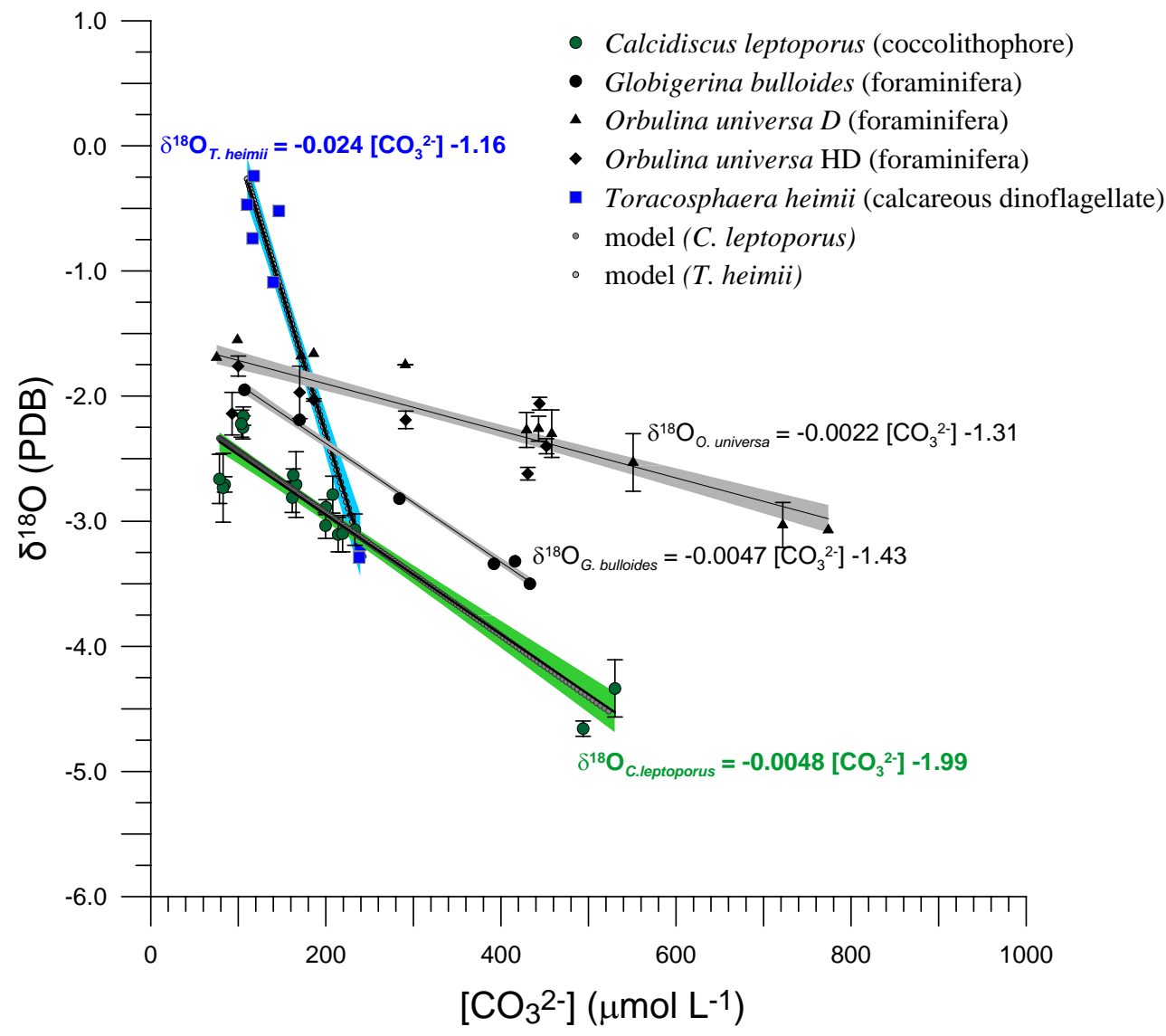

Fig. 1. Effect of $\left[\mathrm{CO}_{3}^{2-}\right]$ on $\delta^{18} \mathrm{O}\left(\delta^{18}\right.$ Ocalcite- $\delta^{18}$ Owater) values of $C$. leptoporus (coccolithophore), T. heimii (calcareous dinoflagellate), $O$. universa $(\mathrm{HL}=$ foraminifera grown under photosynthetic maximum light levels, $\mathrm{D}=$ maintained in the dark) (Spero et al., 1997), and G. bulloides (Spero et al., 1997) (lines are linear regressions fitted to the data). The regression slopes are $-0.0022 \%$ ( $\left.\mu \mathrm{mol} \mathrm{kg}^{-1}\right)^{-1}$ for $O$. universa $(\mathrm{HL}=$ high light; $\mathrm{DC}=$ dark conditions $),-0.0048 \%$ $\left.(\mu \mathrm{mol} \mathrm{kg})^{-1}\right)^{-1}$ for C. leptoporus, $-0.0047 \%$ o $\left(\mu \mathrm{mol} \mathrm{kg}^{-1}\right)^{-1}$ for

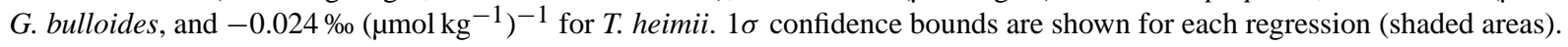

results in T. heimii presented in Gussone et al. (2010) showing strong resemblance with values recorded in planktonic foraminifera thus, supporting the similarities in calcification mechanisms proposed by our model. The extracellular calcification space of foraminifera is isolated from the seawater by a so called pseudopodial network, so that, in effect, also foraminifera calcify in a space which is isolated by means of plasmamembrane not only from the seawater, but also from the cytoplasm (Erez, 2003). This common basic feature of the calcification of the three phylogenetically distinct groups of calcifiers, coccolithophores, foraminifera, and dinoflagellates, can partly account for the fact that it is possible to formulate one single model explaining the dependency of $\delta^{18} \mathrm{O}$ on carbonate chemistry as will be discussed below.

Zuddas and Mucci (1998) and Kim et al. (2006) demonstrated that for an alkaline $\mathrm{pH}$, the kinetics of $\mathrm{CaCO}_{3}$ precipitation are dominated by the reaction: $\mathrm{Ca}^{2+}+$ $\mathrm{CO}_{3}^{2-}=\mathrm{CaCO}_{3}$. Assuming that calcium carbonate is precipitated mainly from carbonate, the $\delta^{18} \mathrm{O}$ composition of the precipitate simply reflects the isotopic composition of $\mathrm{CO}_{3}^{2-}$ in the vesicle. Since at alkaline $\mathrm{pH}$ values $\mathrm{CO}_{3}^{2-}$ is the major carbon source for $\mathrm{CaCO}_{3}$ it is seems reasonable to assume that the uptake of both $\mathrm{CO}_{3}^{2-}$ and $\mathrm{HCO}_{3}^{-}$from the surrounding medium contributes to the $\mathrm{CO}_{3}^{2-}$ pool in the vesicle. The uptake of $\mathrm{CO}_{3}^{2-}$ is assumed to yield a pool size proportional to $\left[\mathrm{CO}_{3}^{2-}\right]$ in the external medium (ext): $f \times\left[\mathrm{CO}_{3}^{2-}\right]_{\text {ext }}$ with $f \leq 1$. Inorganic carbon transported into the vesicle (V) as $\mathrm{HCO}_{3}^{-}$is converted to $\mathrm{CO}_{3}^{2-}$, and the $\left[\mathrm{CO}_{3}^{2-}\right]_{\mathrm{V}}$ increases until supersaturation with respect to calcite is obtained in the vesicle and calcium carbonate starts to precipitate at $\left[\mathrm{CO}_{3}^{2-}\right]_{\mathrm{V}}=\left[\mathrm{CO}_{3}^{2-}\right]_{\mathrm{sat}}$. The contribution of bicarbonate conversion to the $\mathrm{CO}_{3}^{2-}$ pool in the vesicle is given by: $\left[\mathrm{CO}_{3}^{2-}\right]_{\text {sat }}-f \times\left[\mathrm{CO}_{3}^{2-}\right]_{\text {ext }}$ (Fig. 2). The $\mathrm{H}^{+}$generated during $\mathrm{CO}_{3}^{2-}$ formation from $\mathrm{HCO}_{3}^{-}$has to be removed from the vesicle to keep the $\mathrm{pH}$ value of the calcifying vesicle constant. 
Table 1. Experimental data from this study: $\mathrm{CO}_{2}(\mu a t m), \mathrm{CO}_{3}=\left(\mu \mathrm{mol} \mathrm{kg}{ }^{-1}\right)$, Omega calcite saturation, $\mathrm{pH}$ (total scale) values, $\alpha$ and $\varepsilon$ fractionation factors (calcite-water) and $\delta^{18} \mathrm{Oc}-\delta^{18} \mathrm{Ow}$ (calcite-water) (PDB).

\begin{tabular}{|c|c|c|c|c|c|c|c|}
\hline species & $\mathrm{CO}_{2} \mu \mathrm{atm}$ & $\mathrm{CO}_{3}=\mu \mathrm{mol} \mathrm{kg}^{-1}$ & Omega calcite & $\mathrm{pH}$ total scale & $\alpha\left(x-\mathrm{H}_{2} 0\right)$ & $\varepsilon\left(x-\mathrm{H}_{2} 0\right)$ & $\delta^{18} \mathrm{Oc}-\delta^{18} \mathrm{OH}_{2} 0$ (PDB) \\
\hline Calcidiscus leptoporus & 953.3 & 78.5 & 1.95 & 7.84 & 1.0278 & 27.84 & -2.66 \\
\hline Calcidiscus leptoporus & 914.6 & 82.6 & 2.06 & 7.86 & 1.0278 & 27.76 & -2.73 \\
\hline Calcidiscus leptoporus & 891.6 & 84.3 & 2.1 & 7.87 & 1.0278 & 27.79 & -2.71 \\
\hline Calcidiscus leptoporus & 636.00 & 103.4 & 2.51 & 8 & 1.0283 & 28.29 & -2.22 \\
\hline Calcidiscus leptoporus & 617.00 & 105.4 & 2.56 & 8 & 1.0283 & 28.26 & -2.25 \\
\hline Calcidiscus leptoporus & 619.00 & 105.6 & 2.56 & 8 & 1.0284 & 28.35 & -2.16 \\
\hline Calcidiscus leptoporus & 377.00 & 161.7 & 3.92 & 8.24 & 1.0277 & 27.68 & -2.81 \\
\hline Calcidiscus leptoporus & 379.00 & 162.8 & 3.95 & 8.24 & 1.0279 & 27.87 & -2.63 \\
\hline Calcidiscus leptoporus & 369.00 & 166 & 4.03 & 8.24 & 1.0278 & 27.79 & -2.71 \\
\hline Calcidiscus leptoporus & 350.3 & 199.7 & 4.97 & 8.26 & 1.0275 & 27.45 & -3.03 \\
\hline Calcidiscus leptoporus & 351.1 & 200.1 & 4.98 & 8.26 & 1.0276 & 27.61 & -2.89 \\
\hline Calcidiscus leptoporus & 332.6 & 207.9 & 5.17 & 8.28 & 1.0277 & 27.71 & -2.79 \\
\hline Calcidiscus leptoporus & 262.00 & 214.1 & 5.2 & 8.4 & 1.0274 & 27.38 & -3.11 \\
\hline Calcidiscus leptoporus & 256.00 & 219.2 & 5.32 & 8.4 & 1.0274 & 27.39 & -3.10 \\
\hline Calcidiscus leptoporus & 237.00 & 233.1 & 5.66 & 8.4 & 1.0274 & 27.42 & -3.07 \\
\hline Calcidiscus leptoporus & 104.2 & 493.8 & 12.29 & 8.72 & 1.0258 & 25.78 & -4.66 \\
\hline Calcidiscus leptoporus & 93 & 530.2 & 13.19 & 8.76 & 1.0261 & 26.11 & -4.34 \\
\hline Thoracosphaera heimii & 205.3 & 239.4 & 3.74 & 8.28 & 1.0273 & 27.29 & -3.19 \\
\hline Thoracosphaera heimii & 208 & 238.2 & 3.72 & 8.01 & 1.0272 & 27.19 & -3.29 \\
\hline Thoracosphaera heimii & 439.9 & 146.4 & 2.29 & 8.01 & 1.0297 & 29.46 & -0.52 \\
\hline Thoracosphaera heimii & 464.1 & 140 & 2.19 & 7.99 & 1.0296 & 30.04 & -1.09 \\
\hline Thoracosphaera heimii & 599.4 & 117.7 & 1.84 & 7.9 & 1.0303 & 30.33 & -0.24 \\
\hline Thoracosphaera heimii & 603.2 & 116.3 & 1.82 & 7.89 & 1.0298 & 29.82 & -0.74 \\
\hline Thoracosphaera heimii & 653.8 & 110.2 & 1.72 & 7.86 & 1.0301 & 30.10 & -0.47 \\
\hline
\end{tabular}

Chemical equilibrium in the intracellular carbon dioxide system is obtained after several seconds (approximately $15 \mathrm{~s}$ at seawater $\mathrm{pH}=8.2$ and $25^{\circ} \mathrm{C}$, Zeebe et al., 1999), which is negligible compared with the $1.4 \mathrm{~h}$ (calculated using data in Langer et al., 2006) required for the formation of one coccolith (of C. leptoporus). The time to establish $\delta^{18} \mathrm{O}$ equilibrium, on the other hand, is one order of magnitude higher than the time required for coccolith formation (see Table 3.3.9 of Zeebe and Wolf-Gladrow, 2001). It is therefore reasonable to assume that the carbon dioxide system in the calcifying vesicle approaches its chemical equilibrium, whereas the $\mathrm{CO}_{3}^{2-}$ in the vesicle will carry the isotopic fingerprint of the inorganic carbon transported from the cytoplasm into the vesicle. Then, the oxygen isotope fractionation factor between the $\mathrm{CO}_{3}^{2-}$ in the vesicle and water is given by:

$$
\begin{aligned}
& \alpha_{\left(\mathrm{V}-\mathrm{H}_{2} \mathrm{O}\right)}=\left(\alpha_{\left(\mathrm{CO}_{3}^{2-}-\mathrm{H}_{2} \mathrm{O}\right)} \times f \times\left[\mathrm{CO}_{3}^{2-}\right]_{\mathrm{ext}}+\alpha_{\left(\mathrm{HCO}_{3}^{-}-\mathrm{H}_{2} \mathrm{O}\right)}\right. \\
& \left.\times\left(\left[\mathrm{CO}_{3}^{2-}\right]_{\text {sat }}-f \times\left[\mathrm{CO}_{3}^{2-}\right]_{\mathrm{ext}}\right)\right) /\left[\mathrm{CO}_{3}^{2-}\right]_{\mathrm{sat}}
\end{aligned}
$$

Two terms contribute to Eq. (1): the first term represents the equilibrium isotopic composition of $\mathrm{CO}_{3}^{2-}$, whereas the second term is the isotopic composition of the ${ }^{18} \mathrm{O}$ enriched $\mathrm{HCO}_{3}^{-}$flux into the calcifying vesicle. Here, we propose an explanation of the different $\delta^{18} \mathrm{O} /\left[\mathrm{CO}_{3}^{2-}\right]$ slopes for unicellular calcifying organisms in terms of dif- ferent availability of external carbonate $\left(f \times\left[\mathrm{CO}_{3}^{2-}\right]_{\text {ext }}\right)$ for the establishment of supersaturation with respect to calcite in the vesicle $\left(\left[\mathrm{CO}_{3}^{2-}\right]_{\mathrm{V}}=\left[\mathrm{CO}_{3}^{2-}\right]_{\mathrm{sat}}\right)$. The $\delta^{18} \mathrm{O}$ of $\mathrm{CO}_{3}^{2-}$ in the vesicle decreases with increasing external carbonate ion concentration since the contribution of bicarbonate conversion $\left(\left[\mathrm{CO}_{3}^{2-}\right]_{\mathrm{sat}}-f \times\left[\mathrm{CO}_{3}^{2-}\right]_{\mathrm{ext}}\right)$ to the $\mathrm{CO}_{3}^{2-}$ pool in the vesicle decreases as $\left[\mathrm{CO}_{3}^{2-}\right]_{\text {ext }}$ rises. According to this process, the $\delta^{18} \mathrm{O}$ slope is influenced by the calcite saturation product $\left(K_{\mathrm{sp}}\right)$ in the calcifying vesicle: $K_{\text {sp }}=\left[\mathrm{CO}_{3}^{2-}\right]_{\text {sat }} \times\left[\mathrm{Ca}^{2+}\right]_{\text {sat. }}$. The $\delta^{18} \mathrm{O} /\left[\mathrm{CO}_{3}^{2-}\right]$ slope becomes steeper with decreasing $K_{\mathrm{sp}}$, which is a function of temperature and to a lesser extent salinity (Mucci, 1983).

It is still a matter of debate which compartment of the cell takes up $\mathrm{Ca}^{2+}$ from the cytoplasm. It has been suggested that the peripheral endoplasmic reticulum (ER) could play this role (Berry et al., 2002). Using the seawater saturation product $\left(K_{\mathrm{sp}}=10^{-6.415} \mathrm{~mol}^{-2} \mathrm{~kg}^{-2}\right.$ at $S=32$ and $T=20^{\circ} \mathrm{C}$ ) and for $\left[\mathrm{Ca}^{2+}\right]_{\text {sat }}$ a typical value for $\left[\mathrm{Ca}^{2+}\right]$ in the ER $\left(500 \mu \mathrm{mol} \mathrm{kg}{ }^{-1}\right.$; Meldolesi and Pozzan, 1998) yields a $\left[\mathrm{CO}_{3}^{2-}\right]_{\text {sat }}$ in the vesicle of $769 \mu \mathrm{mol} \mathrm{kg}{ }^{-1}$. The oxygen isotope fractionation factors $(\alpha)$ between DIC species and water can be calculated using the equations derived by Beck et al. (2005). In freshwater at $20^{\circ} \mathrm{C}$ (applicable to $C$. leptoporus experiments), the fractionation factors between $\mathrm{HCO}_{3}^{-}, \mathrm{CO}_{3}^{2-}$ and water are $\alpha_{\left(\mathrm{HCO}_{3-}-\mathrm{H}_{2} \mathrm{O}\right)}=1.0325$ and $\alpha\left(\mathrm{CO}_{3}^{2-}-\mathrm{H}_{2} \mathrm{O}\right)=1.0254$. At $17^{\circ} \mathrm{C}(T$. heimii 


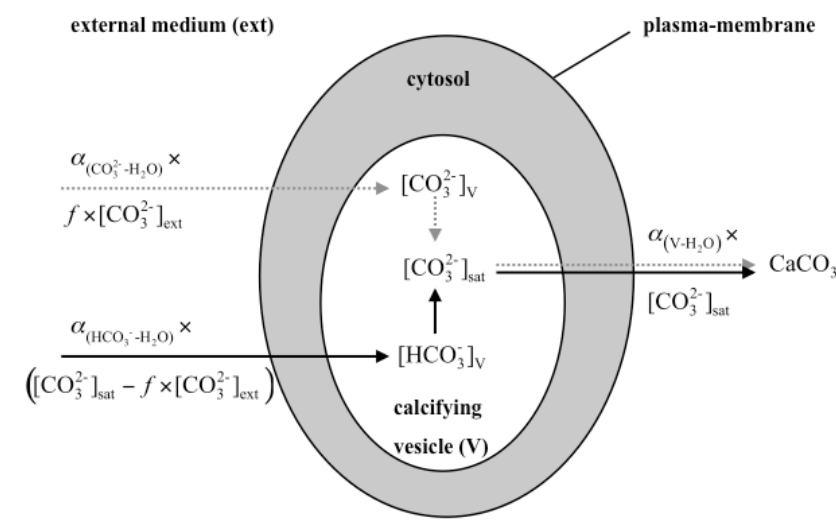

Fig. 2. Proposed fractionation mechanism. Calcium carbonate is precipitated mainly from carbonate, therefore the $\delta^{18} \mathrm{O}$ composition of the precipitate simply reflects the isotopic composition of $\mathrm{CO}_{3}^{2-}$ in the vesicle. The uptake of both $\mathrm{CO}_{3}^{2-}$ and $\mathrm{HCO}_{3}^{-}$from the surrounding medium contributes to the establishment of the $\mathrm{CO}_{3}^{2-}$ pool in the vesicle. The uptake of $\mathrm{CO}_{3}^{2-}$ is assumed to yield a pool size proportional to $\left[\mathrm{CO}_{3}^{2-}\right]$ in the external medium (ext): $f \times\left[\mathrm{CO}_{3}^{2-}\right]$ ext with $f \leq 1$. The inorganic carbon transported into the vesicle $(\mathrm{V})$ as $\mathrm{HCO}_{3}^{-}$is converted to $\mathrm{CO}_{3}^{2-}$, and the $\left[\mathrm{CO}_{3}^{2-}\right]_{\mathrm{V}}$ increases until supersaturation with respect to calcite is obtained in the vesicle and calcium carbonate starts to precipitate at $\left[\mathrm{CO}_{3}^{2-}\right]_{\mathrm{V}}=\left[\mathrm{CO}_{3}^{2-}\right]_{\mathrm{sat}}$. The contribution of bicarbonate conversion to the $\mathrm{CO}_{3}^{2-}$ pool in the vesicle is given by: $\left[\mathrm{CO}_{3}^{2-}\right]_{\text {sat }}-f \times\left[\mathrm{CO}_{3}^{2-}\right]_{\text {ext }}$.

experiments), the freshwater fractionation factors are $\alpha_{\left(\mathrm{HCO}_{3-}-\mathrm{H}_{2} \mathrm{O}\right)}=1.0332$ and $\alpha_{\left(\mathrm{CO}_{3}^{2-}-\mathrm{H}_{2} \mathrm{O}\right)}=1.0260$. We applied Eq. (1) using the freshwater $\alpha$ factors at $20^{\circ} \mathrm{C}$ to simulate the $\delta^{18} \mathrm{O} /\left[\mathrm{CO}_{3}^{2-}\right]$ slope for $C$. leptoporus. The measured slope of coccolith $\delta^{18} \mathrm{O}$ vs. $\left[\mathrm{CO}_{3}^{2-}\right]$ coincides with the calculated slope for $\mathrm{CO}_{3}^{2-}$ in the vesicle $\left(-0.0048 \% \text { o }(\mu \mathrm{mol} \mathrm{kg})^{-1}\right)^{-1}$, see Fig. 1). This slope would require $f=0.53$ using the proposed model. The model also applies to other calcifiers that possess a vesicle-based calcification mechanism, such as the foraminifera $O$. universa and $G$. bulloides. The shallower slope of $O$. universa $\left.\left(-0.0022 \% \text { o }(\mu \mathrm{mol} \mathrm{kg})^{-1}\right)^{-1}\right)$ indicates that a considerable amount of $\mathrm{CO}_{3}^{2-}$ in the vesicles of $O$. universa is derived from bicarbonate conversion and requires a $f$ factor value of 0.24 .

Note that while $\delta^{18} \mathrm{O}$ slopes can be calculated using Eq. (1), absolute $\delta^{18} \mathrm{O}$ values of $\mathrm{CO}_{3}^{2-}$ in the vesicle, and thereby of the precipitated calcite, cannot be compared. The reason for this is that fractionation factors provided by Beck et al. (2005) refer to freshwater, whereas cells were grown at a salinity of 32 . However, the seawater saturation product (at $S=32$ ) is not necessarily appropriate for understanding calcite precipitation and ${ }^{18} \mathrm{O}$ fractionation in unicellular calcifying marine organisms. Coccolithophores, for in- stance, exert strong control over the chemical composition of the calcifying fluid. The ionic strength inside the coccolith vesicle is most likely lower than that of seawater (Anning et al., 1996). In fact, the very steep $\delta^{18} \mathrm{O}$ slope observed in culture experiments with T. heimii $(-0.024 \%$ o $(\mu \mathrm{mol} \mathrm{kg}-1)^{-1}$ ) could be explained in terms of a salinity at the site of calcification $\left(S_{\mathrm{V}}\right)$ of 14.64 , which is less than half of the salinity in seawater. Based on the saturation product $\left(K_{\mathrm{sp}}=10^{-6.803} \mathrm{~mol}^{-2} \mathrm{~kg}^{-2}\right.$ at $S_{\mathrm{V}}=14.64$ and $T=$ $\left.17^{\circ} \mathrm{C}\right)$, a $\left[\mathrm{Ca}^{2+}\right]_{\mathrm{sat}}$ of $500 \mu \mathrm{mol} \mathrm{\textrm {kg } ^ { - 1 }}$ would correspond to a $\left[\mathrm{CO}_{3}^{2-}\right]_{\text {sat }}$ in the vesicle of $315 \mu \mathrm{mol} \mathrm{kg}{ }^{-1}$. Using this value for $\left[\mathrm{CO}_{3}^{2-}\right]_{\mathrm{sat}}$ in the vesicle and the freshwater $\alpha$ factors at $17^{\circ}$, the slope of calcite $\delta^{18} \mathrm{O}$ vs. $\left[\mathrm{CO}_{3}^{2-}\right]$ can be fitted using Eq. (1) by assuming a maximum access to the external $\mathrm{CO}_{3}^{2-}$ during calcite precipitation in the vesicle, i.e. $f=1$ (see Fig. 2).

\section{Conclusions}

In conclusion, the results presented here show that the negative slope of the $\delta^{18} \mathrm{O} /\left[\mathrm{CO}_{3}^{2-}\right]$ relationship that has been recorded in planktic foraminifera is also exhibited by two phylogenetically remote groups of unicellular calcifiers, namely cocolithophores and dinoflagellates. The negative slopes are explained for the first time by a conceptual model that takes physiological mechanisms into consideration. According to the model, the dependence of $\delta^{18} \mathrm{O}$ on carbonate chemistry is mediated through a contribution of $\mathrm{HCO}_{3}^{-}$to the $\mathrm{CO}_{3}^{2-}$ pool in the calcifying compartment.

Previous attempts have been made to correct the foraminiferal $\delta^{18} \mathrm{O}$ proxy for variations of paleo- $\left[\mathrm{CO}_{3}^{2-}\right]$ using the experimental slopes during time-windows when seawater carbonate chemistry was notably different. The new results demonstrate similar $\delta^{18} \mathrm{O} /\left[\mathrm{CO}_{3}^{2-}\right]$ slopes $(0.0048-$ $\left.0.0022\left(\mu \mathrm{mol} \mathrm{kg}{ }^{-1}\right)^{-1}\right)$ for planktic foraminifera and coccolithophores. A strong isotopic fractionation is indicated by the steep slope recorded for a calcareous dinoflagellate. There is considerable scope for further exploration of oxygen isotope composition as a tool for paleo- $\left[\mathrm{CO}_{3}^{2-}\right]$ reconstruction by comparison of coccolithophore and dinoflagellate taxa that share (or shared) the same habitat. With the proposed model in mind, further comparative studies on other species of these groups of planktonic calcifiers could provide important mechanistic insights into intra- and inter-group similarities and/or differences in calcification processes. Such studies would also help to assess the degree of bias introduced into $\delta^{18} \mathrm{O}$-based SST reconstructions by past changes in ocean carbonate chemistry. 
Acknowledgements. We thank $\mathrm{T}$. Toyofuku, an anonymous reviewer and the assigned $\mathrm{CP}$ editor $\mathrm{H}$. Kitazato for their constructive comments. This research is made possible thanks to the support from the EU FP7 MedSeA project (grant agreement no. 265103), the Spanish Ministry of Science and Innovacion cofunded by the European Fund and FP6 MarinERA (CTM2008-04365-E; CGL2009-10806), The Netherlands Organisation for Scientific Research and the German National Science Foundation DFG grant TH744/2-3. This work was funded in part by The European Research Council (ERC grant 2010-NEWLOG ADG-267931 HE).

Edited by: H. Kitazato

\section{References}

Anning, T., Nimer, N., Merrett, M. J., and Brownlee, C.: Costs and benefits of calcification in coccolithophorids, J. Mar. Syst., 9, 45-56, 1996.

Baumann, K.-H., Andruleit, H., Böckel, B., Geisen, M., and Kinkel, H.: The significance of extant coccolithophores as indicators of ocean water masses, surface water temperature, and paleoproductivity: a review, Paläontolog. Zeitschr., 79/1, 93-112, 2005.

Beck, W. C., Grossmann, E. L., and Morse, J. W.: Experimental studies of oxygen isotope fractionation in the carbonic acid system at $15^{\circ}, 25^{\circ}$, and $40^{\circ} \mathrm{C}$, Geochim. Cosmochim. Acta, 69, 3493-3503, 2005.

Bentov, S., Brownlee, C., and Erez, J.: The role of seawater endocytosis in the biomineralization process in calcareous foraminifera, Proceedings of the National Academy of Sciences, 51, 2150021504, 2009.

Bemis, B. E., Spero, H., Bijma, J., and Lea, D.: Reevaluation of the oxygen isotopic composition of planktonic foraminifera: Experimental results and revised paleotemperature equations, Paleoceanography, 13, 150-160, 1998.

Berry, L., Taylor, A. R., Lucken, U., Ryan, K. P., and Brownlee, C.: Calcification and inorganic carbon acquisition in coccolithophores, Functional Plant Biology, 29, 289-299, 2002.

Bijma, J., Spero, H. J., and Lea, D. W.: Reassessing Foraminiferal Stable Isotope Geochemistry: Impact of the Oceanic Carbonate System (Experimental Results), in: Use of Proxies in Paleooceanography: Examples from the South Atlantic, edited by: Fischer, G. a. G. W., Springer Verlag, Berlin Heidelberg, 1999.

Bradshaw, A. L., Brewer, P. G., Shaffer, D. K., and Williams, R. T.: Measurements of total carbon dioxide and alkalinity by potentiometric titration in the GEOSECS program, Earth Planetary Sc. Lett., 55, 99-115, 1981.

Brewer, P. G., Bradshaw, A. L., and Williams, R. T.: Measurement of total carbon dioxide and alkalinity in the North Atlantic ocean in 1981, in: The Changing Carbon Cycle - A Global Analysis, edited by: Trabalka, J. R. and Reichle, D. E., Springer Verlag, New York, 1986.

Broecker, W. and Clark, E.: Ratio of coccolith $\mathrm{CaCO}_{3}$ to foraminifera $\mathrm{CaCO}_{3}$ in late Holocene deep sea sediments, Paleoceanography, 24, PA3205, doi:10.1029/2009PA001731, 2009.

Dickson, A. G. and Millero, F. J.: A comparison of the equilibrium constants for the dissociation of carbonic acid in seawater media, Deep-Sea Res., 34, 1733-1743, 1987.

Erez, J.: The source of ions for biomineralization in foraminifera and their implications for paleoceanographic proxies, Reviews in Mineralogy and Geochemistry, 54, 115-149, 2003.

Erez, J. and Luz, B.: Experimental paleotemperature equation for planktonic foraminifera, Geochim. Cosmochim. Acta, 47, 6, 1025-1031, 1983.

Gran, G.: Determination of the equivalence point in potentiometric titrations of seawater with hydrochloric acid, Oceanologica Acta, 5, 209-218, 1952.

Guillard, R. R. L. and Ryther, J. H.: Studies of marine planktonic diatoms, I, Cyclotella nanna (Hustedt) and Detonula convervacea (Cleve), Canadian Journal of Microbiology, 8, 229-239, 1962.

Gussone, N., Zonnefeld, K., and Kuhnert, H.: Minor element and $\mathrm{Ca}$ isotope composition of calcareous dinoflagellate cysts of Thoracosphaera heimii, Earth Planetary Sc. Lett., 289, 180-188, 2010.

Hoppe, C., Langer, G., and Rost, B.: Emiliania huxleyi shows identical responses to elevated $p \mathrm{CO}_{2}$ in TA and DIC manipulations, J. Exp. Mar. Biol. Ecol., 406, 54-62, doi:10.1016/j.jembe.2011.06.008, 2011.

Inouye, I. and Pienaar, R. N.: Observations on the life cycle and microanatomy of Thoracosphaera heimii (Dinophyceae) with special reference to its systematic position, S. Afr. J. Bot., 2, 63-75, 1983.

Katz, M. E. , Cramer, B. S., Franzese, A., Hönisch, B., Miller, K. G., Rosenthal, Y., and Wright, J. D.: Traditional and emerging geochemical proxies in foraminifera, The Journal of Foraminiferal Research, 40, 165-192, 2010.

Kim, S.-T., Hillaire-Marcel, C., and Mucci, A.: Mechanisms of equilibrium and kinetic oxygen isotope effects in synthetic aragonite at $25^{\circ} \mathrm{C}$, Geochim. Cosmochim. Acta, 70, 5790-5801, 2006.

Langer, G., Geisen, M., Baumann, K.-H., Kläs, J., Riebesell, U., Thoms, S., and Young, J. R.: Species-specific responses of calcifying algae to changing seawater carbonate chemistry, Geochem. Geophys. Geosyst., 7, Q09006, doi:10.1029/2005GC001227, 2006.

Lewis, E. and Wallace, D. W. R.: Program Developed for $\mathrm{CO}_{2}$ System Calculations ORNL/CDIAC-105. Carbon Dioxide Information Analysis Centre, Oak Ridge National Laboratory, US Department of Energy, Oak Ridge, Tennessee, 1998.

Mehrbach, C., Culberson, C. H., Hawley, J. E., and Pytkovicz, R. M.: Measurement of the apparent dissociation constants of carbonic acid in seawater at atmospheric pressure, Limnol. Oceanogr., 18, 897-907, 1973.

Meldolesi, J. and Pozzan, T.: The endoplasmic reticulum $\mathrm{Ca}^{2+}$ store: A view from the lumen, Trends Biochem. Sci., 23, 1014, 1998.

Milliman, J. D.: Production and accumulation of calcium carbonate in the ocean - budget of a nonsteady state, Global Biogeochem. Сy., 7, 927-957, 1993.

Mucci, A.: The solubility of calcite and aragonite in seawater at various salinities, temperatures, and one atmosphere total pressure, Am. J. Sci., 283, 780-799, 1983.

Schulz, K. G., Barcelos e Ramos, J., Zeebe, R. E., and Riebesell, $\mathrm{U}$.: $\mathrm{CO}_{2}$ perturbation experiments: similarities and differences between dissolved inorganic carbon and total alkalinity manipulations, Biogeosciences, 6, 2145-2153, doi:10.5194/bg-6-21452009, 2009.

Spero, H. J.: Ultrastructural examination of chamber morphogenesis and biomineralization in the planktonic foraminifer Orbulina 
universa, Mar. Biol., 99, 9-20, 1988.

Spero, H., Bijma, J., Lea, D. W., and Bemis, B. E.: Effect of seawater carbonate concentration on foraminiferal carbon and oxygen isotopes, Nature, 390, 497-500, 1997.

Stoll, M. H. C., Bakker, K., Nobbe, G. H., and Haese, R. R.: Continuous-flow analysis of dissolved inorganic carbon content in seawater, Anal. Chem., 73, 4111-4116, 2001.

Stoll, H. M. and Ziveri, P.: Coccolithophore-based geochemical proxies, in: Coccolithophores: From Molecular Processes to Global Impact, edited by: Thierstein, H. a. Y., Springer Verlag, Germany, 2004.

Thierstein, H. R. and Young, J. R.: Coccolithophores: From Molecular Processes to Global Impact, Springer, Germany, 2004.

Young, J. R., Davis, S. A., Bown, P. R., and Mann, S.: Coccolith ultrastructure and biomineralisation, J. Struct. Biol., 126, 195215, 1999.

Zeebe, R. E.: An explanation of the effect of seawater carbonate concentration on foraminiferal oxygen isotopes, Geochim Cosmochimica Acta, 63, 2001-2007, 1999.

Zeebe, R. E., Wolf-Gladrow, D. A., and Jansen, H.: On the time required to establish chemical and isotopic equilibrium in the carbon dioxide system in sea water, Mar. Chem., 65, 135-153, 1999.
Zeebe, R. E. and Wolf-Gladrow, D.: $\mathrm{CO}_{2}$ in sea water: equilibrium, kinetics, isotopes, Elsevier Oceanography Series, 65, Amsterdam, 2001.

Ziveri, P., Stoll, H., Probert, I., Klaas, C., Geisen, M., Ganssen, G., and Young, J.: Stable isotope "vital effects" in coccolith calcite, Earth Planet. Sci. Lett., 210, 137-149, 2003.

Ziveri, P., de Bernardi, B., Baumann, K.-H., Stoll, H. M., and Mortyn, P. G.: Sinking of coccolith carbonate and potential contribution to organic carbon ballasting in the deep ocean, Deep Sea Research Part II: Topical Studies in Oceanography, 54, 659-675, 2007.

Zonneveld, K. A. F., Mackensen, A., and Baumann, K. H.: Stable oxygen isotopes of Thoracosphaera heimii (Dinophyceae) in relationship to temperature; a culture experiment, Mar. Micropaleont., 64, 80-90, 2007.

Zuddas, P. and Mucci, A.: Kinetics of calcite precipitation from seawater: II. The influence of the ionic strength, Geochim. Cosmochim. Acta, 62, 757-766, 1998. 